\title{
A TP53-mutáció-analízis jelentősége krónikus lymphocytás leukaemiában
}

\author{
Fésüs Viktória ${ }^{1}$ - Marosvári Dóra dr. ${ }^{1}$ - Kajtár Béla dr. ${ }^{2}$ \\ Király Péter Attila dr. ${ }^{1}$ - Demeter Judit dr. ${ }^{3}$ - Gurbity Pálfi Tímea dr. ${ }^{4}$ \\ Egyed Miklós dr. ${ }^{5}$ - Plander Márk dr. ${ }^{6}$ - Farkas Péter dr. ${ }^{7}$ \\ Mátrai Zoltán dr. ${ }^{8}$ - Matolcsy András dr. ${ }^{1}$ - Bödör Csaba dr. ${ }^{1}$
}

\begin{abstract}
${ }^{1}$ Magyar Tudományos Akadémia-Semmelweis Egyetem Lendület Molekuláris Onkohematológia Kutatócsoport, Semmelweis Egyetem, Általános Orvostudományi Kar, I. Patológiai és Kísérleti Rákkutató Intézet, Budapest ${ }^{2}$ Pécsi Tudományegyetem, Általános Orvostudományi Kar, Patológiai Intézet, Pécs

${ }^{3}$ Semmelweis Egyetem, Általános Orvostudományi Kar, I. Belgyógyászati Klinika, Budapest ${ }^{4}$ Szegedi Tudományegyetem, Általános Orvostudományi Kar, II. Belgyógyászati Klinika, Szeged ${ }^{5}$ Somogy Megyei Kaposi Mór Oktató Kórház, Kaposvár ${ }^{6}$ Markusovszky Egyetemi Oktató Kórház, Szombathely ${ }^{7}$ Semmelweis Egyetem, Általános Orvostudományi Kar, III. Belgyógyászati Klinika, Budapest ${ }^{8}$ Egyesített Szent István és Szent László Kórház, Hematológiai és Őssejt-transzplantációs Osztály, Budapest
\end{abstract}

\begin{abstract}
Bevezetés: Az elmúlt években jelentős előrelépések történtek a krónikus lymphocytás leukaemia kezelésében, ugyanis az új innovatív gyógyszerek a TP53-defektust hordozó csoportban is hatékonynak bizonyultak. Ezen betegek maradéktalan azonosításához elengedhetetlen a TP53-defektus mindkét formájának (17p-deletio és TP53-mutációk) vizsgálata. A TP53-mutációk vizsgálata ma a nemzetközi ajánlások részét képezi, segítséget nyújtva az optimális terápiás stratégia megalkotásában. Célkitüzés: Jelen tanulmány célja a TP53-mutációk előfordulásának és a 17p-deletióhoz való viszonyának meghatározása, valamint a mutációk rutindiagnosztikus kimutatására alkalmas szekvenálási eljárás beállítása volt. Módszer: A mutációanalízist Sanger-szekvenálással végeztük el 196, krónikus lymphocytás leukaemiában szenvedő beteg esetében. Eredmények: A betegek 15,8\%-ában azonosítottunk TP53-mutációt, ami az esetek felében 17p-deletio nélkül fordult elő. A TP53-defektus mindkét formájának vizsgálatával összesen a betegek 25,4\%ánál azonosítottunk TP53-defektust. Következtetések: A mutációanalízis elvégzésével további 10\% magas rizikójú beteg azonosítható, akik számára a legjobb választást az ebben a betegcsoportban is hatékony új célzott terápiák jelentik. Orv. Hetil., 2017, 158(6), 220-228.
\end{abstract}

Kulcsszavak: krónikus lymphocytás leukaemia, TP53, célzott terápia

\section{TP53 mutation analysis in chronic lymphocytic leukaemia}

Introduction: In recent years much progress has been made in the therapy of chronic lymphocytic leukaemia, as the new innovative medicine proved to be effective in managing patients carrying TP53 abnormalities. To identify all these patients, it is essential to screen for both forms of TP53 defects, including both 17p deletions and TP53 mutations. Aim: The aim of this study was to determine the frequency of TP53 mutations and their association with $17 \mathrm{p}$ deletions in a large Hungarian cohort of 196 patients suffering from chronic lymphocytic leukaemia. Method: We performed mutation analysis of TP53 (exons 3-10) using Sanger sequencing. Results: TP53 mutations were present in $15.8 \%$ of patients, half of which were associated with $17 \mathrm{p}$ deletion. By analysing both forms, TP53 defect was identified in $25.4 \%$ of the patients. Conclusions: Our study demonstrates that by performing a TP53 mutation analysis, an additional $10 \%$ of high-risk patients can be detected.

Keywords: chronic lymphocytic leukaemia, TP53, targeted therapy

Fésüs, V., Marosvári, D., Kajtár, B., Király, P. A., Demeter, J., Gurbity Pálfi, T., Egyed, M., Plander, M., Farkas, P., Mátrai, Z.,Matolcsy, A., Bödör, Cs. [TP53 mutation analysis in chronic lymphocytic leukaemia]. Orv. Hetil., 2017, $158(6), 220-228$.

(Beérkezett: 2016. november 3.; elfogadva: 2016. november 30.) 
A tumorprotein p53 (TP53) a legfontosabb humán tumorszuppresszor fehérje, amelyben az első mutációkat 1989-ben írták le tüdő- [1] és colorectalis daganatokban [2]. A TP53 fehérje számos jelátviteli út szabályozásával központi szerepet tölt be a DNS-károsodásra adott válasz koordinálásában és a daganatképződés megakadályozásában (1. ábra). Funkciója, jellemzően rossz prognózissal társulva, a szolid tumorok több mint 50\%-ában károsodik, így a humán daganatokban leggyakrabban érintett génként tartjuk számon $[3,4]$. Bár a hematológiai daganatok esetén ritkábban, mintegy 20\%-ban fordul elő TP53-diszfunkció, megjelenése szoros összefüggést mutat a rövid túléléssel, transzformációval és kemorezisztenciával, különösen krónikus lymphocytás leukaemia (CLL) esetében [5].

A CLL a leggyakoribb felnőttkori leukaemia a nyugati országokban, Magyarországon az incidenciája 3-5/100 000 lakos/év, ami az összes leukaemia mintegy 25-30\%-át teszi ki. A kórképet heterogén klinikai megjelenés jellemzi, míg a betegek egy része évekig nem igényel kezelést, az esetek közel egyharmadában agresszív lefolyás, gyakori relapsus, kemorezisztencia és rövid túlélés jellemző [6]. Dacára a technológia soha nem látott fejlődési ütemének, a CLL továbbra is gyógyíthatatlan betegség. Az elmúlt években a kedvezőtlen prognózis hátterében az új generációs szekvenálás (NGS) segítségével több gén mutációja is azonosításra került, amelyek közül kiemelt jelentőséggel bírnak a TP53 gént érintő genetikai eltérések [7-10]. Bár CLL-ben az első TP53mutációkat és azok összefüggését a kedvezőtlen kimenetellel már 1991-ben leírták, prognosztikai jelentőségükre és a betegek rövidebb túlélésével való szoros összefüggésre az új NGS-tanulmányok világítottak rá ismét [8, 11, 12]. A TP53-defektust hordozó betegeket kemo-, illetve kemo-immuno terápiával kezelve a terápiás válasz alacsony, esetükben komplett remisszió (CR) alig érhető el, a progressziómentes túlélés (PFS) egy-két év, míg a teljes túlélés (OS) mindössze két-három év [13, 14]. A TP53-defektus patogén voltát a betegség lefolyása során bizonyítja, hogy gyakorisága a diagnóziskori 5-10\%ról a kemorezisztens esetekben 40\%-ra [13], míg Richter-szindróma esetén 60\%-ra nő [15].

Az elmúlt években jelentős előrelépés történt a CLL kezelésében: az újonnan megjelent innovatív gyógyszerek (tirozinkináz-inhibitorok, Bcl-2-inhibitorok) a legkedvezőtlenebb prognózissal bíró TP53-deficiens betegcsoport esetében is hatékonynak bizonyultak [16-18], ezért mára kiemelten fontossá vált a TP53-státusz vizsgálata. A TP53-mutációkat hordozó betegek túlélése megegyezik a 17p-deletiót hordozókéval, ezért az irodalomban a két laesio együtt TP53-defektus néven szerepel $[14,19,20]$. A defektus két formája gyakran fordul elő együtt, ebben az esetben az egyik allélon deletio, míg a másik allélon mutáció figyelhető meg (2. ábra). Míg a 17p-deletiót közel 80\%-ban kísérheti TP53-mutáció [21], addig a mutációk gyakrabban (mintegy 50\%-ban) fordulnak elő deletio nélkül [22]. Az optimális terápiás stratégia megválasztása szempontjából jelenleg a TP53státusz a legfontosabb prognosztikai marker, amelynek pontos meghatározásához a TP53-mutációt $17 \mathrm{p}$-deletio nélkül hordozó betegek azonosítása is elengedhetetlen. A TP53-mutációk kimutatására az Európai LeukemiaNet CLL munkacsoportja (European Research Initiative on CLL - ERIC) által közölt nemzetközi ajánlás alapján a Sanger-szekvenálással történő mutációanalízis alkalmazandó [23], azonban szemben a 17p-deletio kimutatására alkalmas fluoreszcens in situ hibridizáció (FISH) módszerével, ez az eljárás hazánkban mindeddig nem volt elérhető.

Munkánk célja Magyarországon elsóként a TP53-mutációk rutindiagnosztikus kimutatására alkalmas szekvenálási eljárás beállítása volt, amelynek segítségével meghatároztuk a TP53-mutációk előfordulását egy nagyszámú hazai CLL-es betegpopuláción.

\section{Módszer}

A TP53-mutációk gyakoriságának meghatározásához hazai CLL-es betegek archivált DNS-mintáit vizsgáltuk. A betegség diagnózisa a Semmelweis Egyetem I. Patológiai és Kísérleti Rákkutató Intézetében 1994-2016 kö-

1. táblázat | Klinikai és biológiai paraméterek

\begin{tabular}{llcc}
\hline Paraméter & & $\begin{array}{c}\text { Betegszám } \\
(\mathrm{n}=196)\end{array}$ & \\
\hline Nem & Nő & 75 & $38 \%$ \\
& Férfi & 121 & $62 \%$ \\
\hline Életkor & & & \\
& $<60$ & 50 & $26 \%$ \\
& $60-69$ & 73 & $37 \%$ \\
& $70-79$ & 53 & $27 \%$ \\
& $80+$ & 20 & $10 \%$ \\
& Átlagéletkor & 66,4 & \\
\hline
\end{tabular}

Kezelés

$\begin{array}{lrc}\text { Igényelt } & 128 & 65 \% \\ \text { Nem igényelt } & 10 & 5 \% \\ \text { NA } & 58 & 30 \%\end{array}$

CD38

$\begin{array}{lll}\text { Pozitív } & 67 & 34 \% \\ \text { Negatív } & 43 & 22 \% \\ \text { NA } & 86 & 44 \%\end{array}$

del17p

$\begin{array}{lrr}\text { Van } & 21 & 11 \% \\ \text { Nincs } & 121 & 62 \% \\ \text { NA } & 54 & 27 \%\end{array}$

$\mathrm{NA}=$ nincs adat 
A

A TP53 gén exonszerkezete (2579 bp)

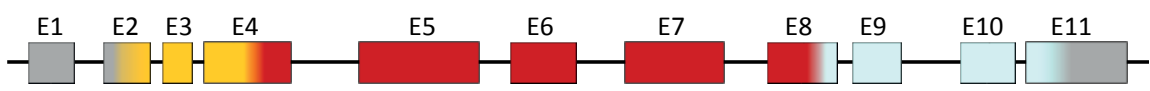

B

A TP53 fehérje aminosav-szerkezete (393 AS)

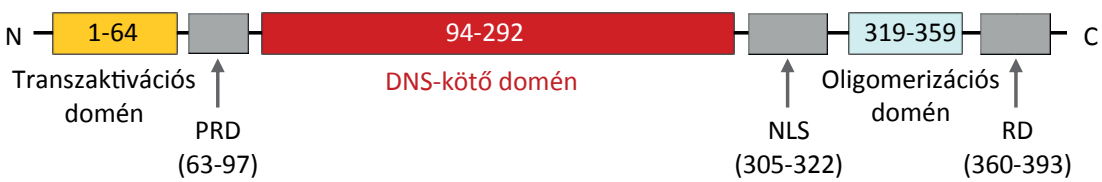

C

A TP53 fehérje funkciója

$\begin{array}{lll} & \text { I. } & \text { Sejtciklus-leállitás } \\ & \text { II. } & \text { DNS-hibajavítás } \\ & \text { III. } & \text { Apoptózis } \\ & \text { IV. } & \text { Angiogenezis-gátlás }\end{array}$

1. ábra

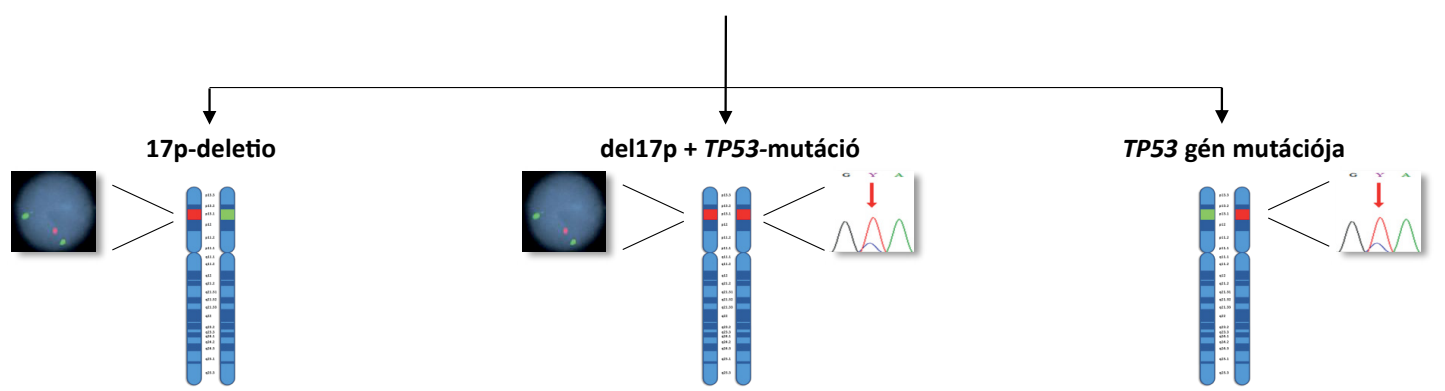

B

\begin{tabular}{|l|c|c|c|}
\hline & 17p13.1-régió & FISH & Sanger-szekvenálás \\
\hline Nincs TP53-defektus & & \\
\hline 17p-deletio & & \\
\hline TP53-mutáció & & \\
\hline TP53-mutáció + 17p-deletio & &
\end{tabular}

2. ábra $\quad$ A TP53-defektus megjelenési formái és a kimutatásukra alkalmazott vizsgálómódszerek. (A) A TP53-defektus létrejöhet 17p-deletióval, TP53-mutációval, valamint a két eltérés előfordulhat együtt is; ekkor az egyik allél deletált, míg a másik allélon mutáció található. A TP53-mutáció szekvenálással, míg a 17 p-deletio fluoreszcens in situ hibridizációval (FISH) detektálható. A B ábrán a TP53-defektus egyes formáinak kimutatása során alkalmazott vizsgálati módszerek szemléletes megjelenítése látható 
zött, az Egészségügyi Világszervezet (World Health Organization - WHO) kritériumai szerint történt [24]. Százkilencvenhat beteg genomiális DNS-mintáját vizsgáltuk meg, amelyek közül 18 nyirokcsomóból, 19 csontvelőből, 159 perifériás vérből származott. A klinikai és biológiai paraméterek megoszlása az 1 . táblázatban látható. Ötvenkilenc beteg esetében a mintavétel a diagnózis idején, 133 betegnél előrehaladottabb stádiumban (aktivitás/relapsus/terápiarezisztencia), négy esetben Richter-transzformáció során történt. A DNS kivonása a mononukleáris sejtfrakció ficoll-lal történő szeparációját követően High Pure PCR template purification kit (Roche) segítségével történt, a gyártó utasításainak megfelelően. Az ERIC által közölt ajánlás alapján a TP53mutációk kimutatását a gén DNS-kötő doménját kódoló régiójának (4-9-es exonok) polimeráz láncreakcióval (PCR) való amplifikációját követő direkt Sanger-szekvenálással végeztük el [23]. Ezenfelül elvégeztük a 3-as és 10-es exonok szekvenálását is, kibővítve a nemzetközi ajánlást. Az eredmények kiértékelésekor kizárólag az aminosavsorrend megváltozását eredményező úgynevezett missense, nonsense és frameshift mutációkat vettük figyelembe, a daganatokban előforduló szomatikus mutációkat tartalmazó COSMIC (Catalogue of Somatic Mutations in Cancer, http://cancer.sanger.ac.uk/cos- mic), valamint a TP53-mutációkat tartalmazó IARC (International Agency for Research on Cancer, http://p53. iarc.fr/) adatbázisok alapján.

\section{Eredmények}

\section{A TP53-mutációk gyakorisága, típusa, génen belüli eloszlása}

A TP53-mutációk gyakoriságának meghatározásához 196 CLL-es beteg esetén végeztük el a mutációanalízist. A betegek 15,8\%-ában (31/196) azonosítottunk mutációt a TP53 gén valamely szakaszában, öt beteg esetében két különböző mutációt is kimutattunk (3. A ábra és 2. táblázat). A mutációk típusa és génen belüli eloszlása a 3. ábrán látható. A mutációk döntő többsége aminosavcserét eredményező missense mutáció volt $(77,8 \%)$, ezt gyakoriságban a stop kodont eredményező nonsense mutációk $(11,1 \%)$ és a leolvasási keret eltolódásával járó frameshift mutációk $(8,3 \%)$ követték, legritkábban a splice mutáció $(2,8 \%)$ fordult elő (3. B ábra). A mutációk génen belüli eloszlását vizsgálva $88,9 \%$-ban a DNSkötő régióban (exon 4-8) helyezkedtek el, gyakran (15/36) érintve a jól ismert szubsztitúciós (R175, Y220, G245, R248, R273 és R282) és inszerciós/deletiós
A TP53-MUTÁCIÓK GYAKORISÁGA (N = 196)

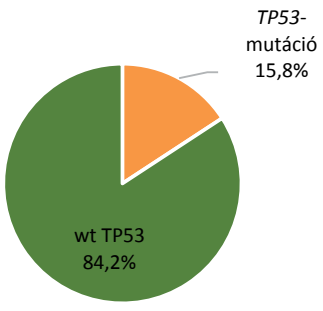

C

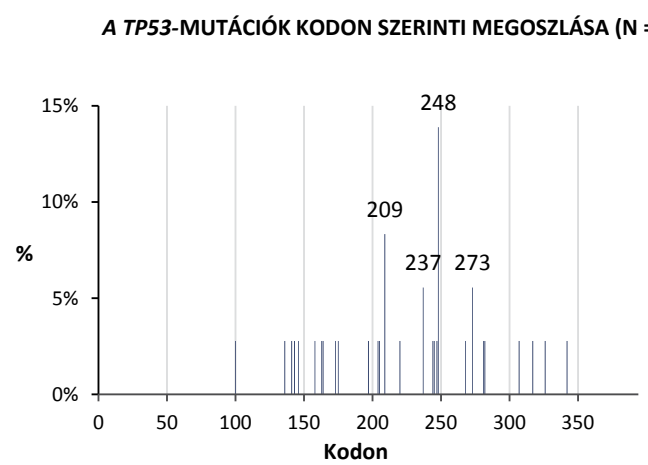

\section{A TP53-MUTÁCIÓK GÉNEN BELÜLI ELOSZLÁSA}

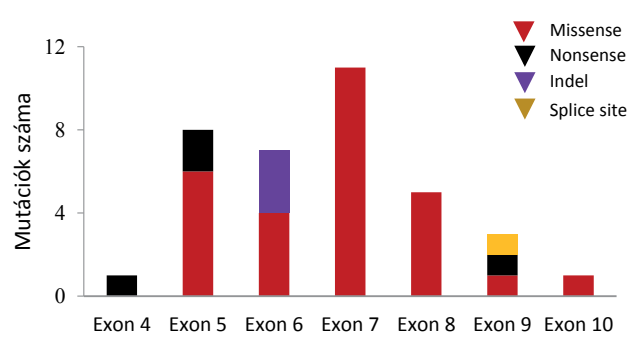

D

A TP53-mutációk gyakorisága és eloszlása az általunk vizsgált betegpopulációban. (A) A betegek 15,8\%-ában azonosítottunk mutációt a TP53 génben. (B) A TP53-mutációk exon szerinti megoszlása. A mutációk 88,9\%-a a DNS-kötő domént kódoló régión helyezkedett el (exon 4-8), többnyire missense mutáció formájában. (C) A TP53-mutációk kodon szerinti megoszlása. A leggyakrabban érintett aminosavak a 209-es, 237-es, 248-as és 273-as pozícióban találhatóak. Klasszikus mutációs forrópontokra, mint 175, 209, 220, 245, 248, 273, 282 és 342, a mutációk 42\%-a (15/36) esett. (D) A TP53-mutációk a fehérjén belül döntően a DNS-kötő doménben helyezkedtek el 
2. táblázat |A tanulmányunkban azonosított TP53-mutációk paraméterei

\begin{tabular}{|c|c|c|c|c|c|c|c|}
\hline Sorszám & Exon & cDNS-pozíció & Aminosav-pozíció & COSMIC-azonosító & Mutáció típusa & Domén & Hatás (IARC) \\
\hline 1. & Exon 4 & c. $298 \mathrm{C}>\mathrm{T}$ & p.Q100* & COSM44032 & nonsense & DBD & Ismeretlen \\
\hline 2. & Exon 5 & c. $406 \mathrm{C}>\mathrm{T}$ & p.Q136* & COSM11166 & nonsense & DBD & Ismeretlen \\
\hline 3. & Exon 5 & c. $427 \mathrm{G}>\mathrm{A}$ & p.Vl43M & COSM220754 & missense & DBD & Káros \\
\hline 4. & Exon 5 & c. $437 \mathrm{G}>\mathrm{A}$ & p.W146* & COSM43609 & nonsense & DBD & Ismeretlen \\
\hline 5. & Exon 5 & c. $473 \mathrm{G}>\mathrm{C}$ & p.Rl58P & COSM43615 & missense & DBD & Káros \\
\hline 6. & Exon 5 & c. $488 \mathrm{~A}>\mathrm{G}$ & p.Yl63C & COSM10808 & missense & DBD & Káros \\
\hline 7. & Exon 5 & c. $490 \mathrm{~A}>\mathrm{G}$ & p.Kl64E & COSM10762 & missense & DBD & Káros \\
\hline 8. & Exon 5 & c. $518 \mathrm{~T}>\mathrm{C}$ & p.V173A & COSM44327 & missense & DBD & Káros \\
\hline 9. & Exon 5 & c.524G $>A$ & p.R175H & COSM10648 & missense & DBD & Káros \\
\hline 10. & Exon 6 & c. $589 \mathrm{G}>\mathrm{C}$ & p.V197L & COSM45265 & missense & DBD & Káros \\
\hline 11. & Exon 6 & c. $612 \mathrm{G}>\mathrm{C}$ & p.E204D & COSM984938 & missense & DBD & Neutrális \\
\hline 12. & Exon 6 & c. $613 \mathrm{~T}>\mathrm{C}$ & p.Y205H & COSM43642 & missense & DBD & Káros \\
\hline 13. & Exon 6 & c.626_627delGA & p.R209fs* 6 & COSM13120 & frameshift & DBD & Ismeretlen \\
\hline 14. & Exon 6 & c.626_627delGA & p.R209fs ${ }^{*} 6$ & COSM13120 & frameshift & DBD & Ismeretlen \\
\hline 15. & Exon 6 & c.626_627delGA & p.R209fs ${ }^{*} 6$ & COSM13120 & frameshift & DBD & Ismeretlen \\
\hline 16. & Exon 6 & c. $659 \mathrm{~A}>\mathrm{G}$ & p.Y220C & COSM10758 & missense & DBD & Káros \\
\hline 17. & Exon 7 & c. $711 \mathrm{G}>\mathrm{A}$ & p.M237I & COSM99648 & missense & DBD & Káros \\
\hline 18. & Exon 7 & c. $711 \mathrm{G}>\mathrm{T}$ & p.M237I & COSM11063 & missense & DBD & Káros \\
\hline 19. & Exon 7 & c. $721 \mathrm{~T}>\mathrm{C}$ & p.S241P & COSM44578 & missense & DBD & Káros \\
\hline 20. & Exon 7 & c. $731 \mathrm{G}>\mathrm{C}$ & p.G244A & COSM12013 & missense & DBD & Káros \\
\hline 21. & Exon 7 & c. $734 \mathrm{G}>\mathrm{A}$ & p.G245D & COSM43606 & missense & DBD & Káros \\
\hline 22. & Exon 7 & c. $739 \mathrm{~A}>\mathrm{T}$ & p.N247Y & COSM43864 & missense & DBD & Káros \\
\hline 23. & Exon 7 & c. $742 \mathrm{C}>\mathrm{G}$ & p.R248G & COSM11564 & missense & DBD & Káros \\
\hline 24. & Exon 7 & c. $743 \mathrm{G}>\mathrm{A}$ & p.R248Q & COSM10662 & missense & DBD & Káros \\
\hline 25. & Exon 7 & c. $743 \mathrm{G}>\mathrm{A}$ & p.R248Q & COSM10662 & missense & DBD & Káros \\
\hline 26. & Exon 7 & c. $743 \mathrm{G}>\mathrm{A}$ & p.R248Q & COSM10662 & missense & DBD & Káros \\
\hline 27. & Exon 7 & c. $743 \mathrm{G}>\mathrm{A}$ & p.R248Q & COSMl0662 & missense & DBD & Káros \\
\hline 28. & Exon 8 & c. $803 \mathrm{~A}>\mathrm{T}$ & p.N268I & Cosm11817 & missense & DBD & Káros \\
\hline 29. & Exon 8 & c. $817 \mathrm{C}>\mathrm{T}$ & p.R273C & COSM10659 & missense & DBD & Káros \\
\hline 30. & Exon 8 & c. $818 \mathrm{G}>\mathrm{A}$ & p.R273H & COSM10660 & missense & DBD & Káros \\
\hline 31. & Exon 8 & c. $841 \mathrm{G}>\mathrm{A}$ & p.D281N & COSM43596 & missense & DBD & Káros \\
\hline 32. & Exon 8 & c. $844 \mathrm{C}>\mathrm{G}$ & p.R282G & COSM10992 & missense & DBD & Káros \\
\hline 33. & Intron $8-9$ & c. $920-1 \mathrm{G}>\mathrm{A}$ & p.307 & COSM6917 & splice & NLS & Ismeretlen \\
\hline 34. & Exon 9 & c. $949 \mathrm{C}>\mathrm{T}$ & p.Q317* & COSM10786 & nonsense & NLS & Ismeretlen \\
\hline 35. & Exon 9 & c. $976 \mathrm{G}>\mathrm{A}$ & p.E326K & COSM4271711 & missense & OD & Káros \\
\hline 36. & Exon 10 & c. $1025 \mathrm{G}>\mathrm{C}$ & p.R342P & COSM45276 & missense & OD & Káros \\
\hline
\end{tabular}

IARC = International Agency for Research of Cancer; DBD = DNS-kötő domén; NLS = nukleáris lokalizációs szignál; OD = oligomerizációs domén. Félkövér szedés: ismert mutációs forrópontok.

(R209) forrópontokat (3. C-D ábra). A betegség progressziójával nőtt a TP53-mutációk gyakorisága, míg diagnóziskor 6,8\%-ban (4/59), addig előrehaladottabb stádiumban 18,7\%-ban (25/133), Richter-transzformáció esetén 50\%-ban $(2 / 4)$ fordult elő TP53-mutáció. A különböző mintatípusok tekintetében a vizsgált perifériás vérminták 15,7\%-ában (25/159), a nyirokcsomó- minták 11,1\%-ában (2/18), míg a csontvelőminták 21,1\%-ában (4/19) mutattunk ki TP53-mutációt.

Mivel jelen retrospektív tanulmányunk fó célja a TP53mutációk kimutatására alkalmas módszer beállítása volt, és a vizsgálati minták egy szelektálatlan, heterogén módon kezelt, úgynevezett historikus betegpopulációból származtak, részleteiben nem vizsgáltuk a TP53-mutá- 
ciók összefüggéseit a klinikai adatokkal. Mindazonáltal a TP53-mutáns esetek döntő többségében (30/31) a betegség lefolyása klinikailag is agresszív volt. A 31 TP53mutáns beteg közül mindössze egyetlen olyan beteget azonosítottunk, aki a 14 éves követési ideje alatt egyszer sem igényelt kezelést, aminek magyarázata lehet, hogy a beteg esetében azonosított TP53-mutáció (p.E204D) az IARC-adatbázis alapján nem okoz p53-diszfunkciót, annak ellenére, hogy a DNS-kötő régióban helyezkedik el [4].

\section{A TP53-mutációk összefüggései a 17p-deletióval}

A 196, általunk vizsgált betegből 142 esetben rendelkeztünk FISH-adattal a 17 p-régió deletióját illetően. A betegek 14,8\%-ában (21/142) azonosítottunk 17p-deletiót, míg TP53-mutációt 20,4\%-ában (29/142) (4. A ábra). A TP53-mutációk gyakran társultak 17p-deletióhoz, a deletiót hordozó betegek 66,7\%-a (14/21) hordozott TP53-mutációt is. Klinikai szempontból jelentős, hogy az intakt 17 p-vel rendelkező betegek 12,4\%-ában (15/121) mutattunk ki TP53-mutációt, a mutációk tehát az esetek felében (15/29) 17p-deletio nélkül, egyedüli eltérésként fordulnak elő. A két vizsgálat eredményeit összegezve, a TP53-mutációk 42\%-ban (15/36) önállóan állnak a TP53-defektus hátterében, további 39\%-ban (14/36) 17p-deletióhoz társulva, míg a betegek 19\%-ában (7/36) a 17p-deletio egyedüli eltérésként jelenik meg (4. B ábra). Összefoglalásul, a TP53-defektus mindkét formájának vizsgálatával összesen a betegek 25,4\%-ánál (36/142) azonosítottunk TP53-defektust (4. A ábra), ami az esetek közel felében $17 \mathrm{p}$-deletio nélkül megjelenő TP53-mutációkat jelent (4. Bábra).

\section{Megbeszélés}

Jelen tanulmányunk célja a TP53-mutációk kimutatására alkalmas diagnosztikus eljárás beállítása és a mutációk gyakoriságának vizsgálata volt hazai betegcsoporton. A betegek 15,8\%-ában azonosítottunk TP53-mutációt, ami az esetek felében 17p-deletio nélkül fordult elő. Utóbbi betegek megfelelő prognosztikai besorolásához szükséges a szekvenálással történő mutációanalízis integrálása a rutindiagnosztikába. Munkánk során az ehhez szükséges szekvenálási vizsgálatot laboratóriumunkban sikeresen beállítottuk és a hazai hematológiai centrumok számára elérhetővé tettük. A TP53-defektus valamely formáját hordozó betegek a Rossi és mtsai által megalkotott legújabb integrált prognosztikai modell alapján is a magas rizikójú csoportba sorolandók [12]. Jelen tanulmányban, a mutációanalízis elvégzésének köszönhetően, a FISH segítségével kimutatható 17p-deletiót mutató eseteken kívül további tizenöt, TP53-defektust hordozó beteget azonosítottunk, ami által a magas rizikójú betegek száma 71\%-os növekedést mutatott (4. ábra).

Bár a TP53-defektus egy erős, független, negatív prognosztikus marker, kezelési indikáció hiányában rutinszerû vizsgálata a betegség diagnózisakor mégsem ajánlott. Ahogy azt Rossi és Gaidano összefoglaló közleményükben megfogalmazták, diagnóziskori pozitív eredmény esetén a továbbra is legoptimálisabbnak bizonyuló, kezdeti „watch and wait” stratégiát felváltaná a „watch and worry”, így lerövidülne az első kezelésig eltelt idő [25]. A TP53-diszfunkció a DNS-károsító kemoterapeutikumokkal szemben szelekciós előnyt jelent, ezért ilyen hatásmechanizmusú kezelést választva a CLLben jól ismert terápia indukálta klonális evolúció jön létre. Ennek során a TP53-mutációt hordozó szubklónok szelekciójára, majd expanziójára kerül sor, ami agresszív
TP53-DEFEKTUSOK MEGOSZLÁSA ( $N=142)$

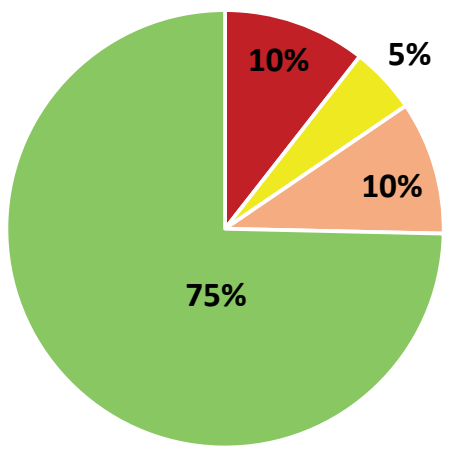

- Csak TP53-mutáció

Csak 17p-deletio

- TP53-mutáció + 17p-deletio együtt

- Nincs TP53-defektus
A TP53-DEFEKTUS FORMÁl $(N=36)$

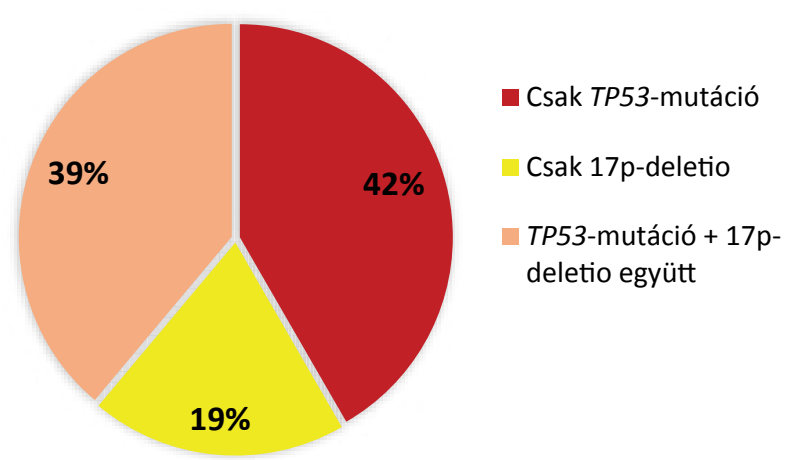


A

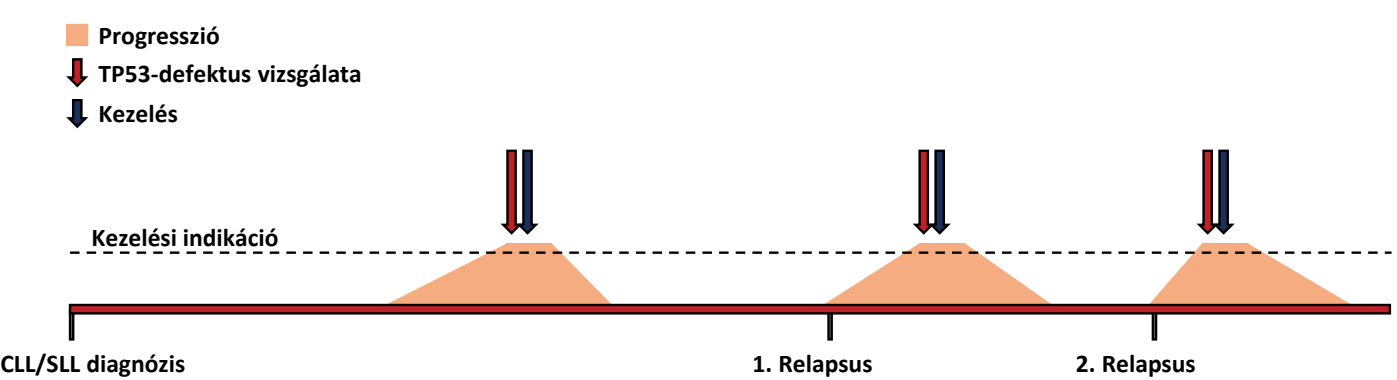

B

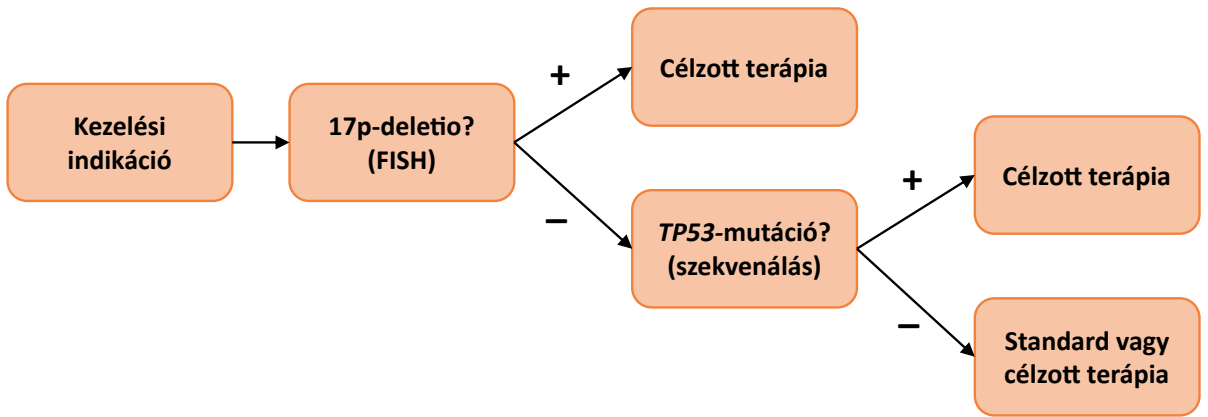

5. ábra

A TP53-státusz vizsgálatának helye a klinikai gyakorlatban. (A) A TP53-státusz vizsgálatának ajánlott ideje a CLL lefolyása során. A vizsgálatot az első kezelés megkezdése előtt érdemes elvégezni, majd minden egyes kezelést igénylő relapsus alkalmával ismételni. (B) Az ábrán egy lehetséges diagnosztikus algoritmus látható a TP53-státusz vizsgálatához első vonalbeli kezelés előtt, valamint az ajánlott terápiás modalitások. Negatív FISH-vizsgálat után érdemes elvégezni a mutációanalízist, hogy a TP53-státusz korrekt ismerete hozzájáruljon a megfelelő terápiás döntéshez

3. táblázat | Nemzetközi ajánlások a TP53-státusz vizsgálatára

\begin{tabular}{llllll}
\hline Ajánlás & Forrás & Év & Folyóirat & Mikor? & Mit? \\
\hline IWCLL & Hallek, et al. & 2008 & Blood & Kezelés előtt & dell7p \\
ERIC & Pospisilova, et al. & 2012 & Leukemia & Kezelés elött & del17p és TP53-mutációk \\
BCSH & Oscier, et al. & 2012 & Br. J. Haematol. & Kezelés előtt & dell7p és TP53-mutációk \\
NCCN & Zelenetz, et al. & 2015 & J. Natl. Compr. Canc. Netw. & Kezelés elótt & del17p és TP53-mutációk \\
ESMO & Eichhorst, et al. & 2015 & Ann. Oncol. & Kezelés előtt & dell7p és TP53-mutációk \\
\hline
\end{tabular}

$\mathrm{BCSH}=$ British Committee for Standards in Haematology; ERIC = European Research Initiative on CLL; ESMO = European Society of Medical Oncology; IWCLL = International Workshop on Chronic Lymphocytic Leukemia, NCCN = National Comprehensive Cancer Network.

klinikai lefolyást eredményez [26]. Mindezek fényében a TP53-státusz vizsgálata nemcsak kezelési indikáció fennállásakor, a kezelés megkezdése előtt ajánlott, hanem ismétlendő minden egyes kezelést igénylő relapsus alkalmával (5. A ábra) [23, 27-30]. Az új ajánlások a TP53-defektust nemcsak a kemoimmunoterápia-rezisztenciát előre jelző biomarkerként, hanem a célzott terápiák egyik indikációjaként is tartalmazzák [27, 31, 32]. TP53-defektus (17p-deletio/TP53-mutáció) esetén mind az úgynevezett 'go-go', mind a 'slow-go' betegeknél kerülendő a standard kemo-immuno terápia, ehelyett különböző célzott terápiás szerek (BTK-inhibitorok, PI3Kinhibitorok) választandók rituximabbal vagy a nélkül, lehetőleg már első vonalbeli kezelésként [33].

$\mathrm{Az}$ egyetlen, általunk azonosított indolens lefolyású TP53-mutációval rendelkező beteg jó példát szolgáltat arra a megfigyelésre, hogy klinikailag nem minden TP53mutáció egyenértékű, ezért érdemes körültekintően eljárni a pozitív eredmény megítélésekor. Tanulmányunkban kizárólag nemzetközi adatbázisok (IARC és COSMIC) alapján igazoltan klinikai relevanciával bíró mutációkat vettünk figyelembe, amelyek elsősorban DNS-kötő régiót kódoló génszakaszon (exon 4-9) elhelyezkedve a p53 fehérje DNS-kötő képességét vagy konformációját változtatják meg, amelynek következtében funkcióvesztéshez vezetnek.

A 3. táblázatban a TP53-defektus vizsgálatának ajánlott módját és idejét tartalmazó nemzetközi ajánlások (ERIC, ESMO, IWCLL, BCSH, NCCN) szerepelnek [23, 27-30]. Az irodalomban leírtak alapján a TP53-mutációk gyakrabban fordulnak elő, mint a 17 p-deletio (3. táblázat), hasonló jelenség látható a hazai betegcso- 
portban is $(29 / 142$ versus $21 / 142)$. Mindezek alapján az agresszív lefolyás hátterét tisztázandó, illetve annak kialakulását megelőzendő ajánlott a mutációk irányába történő vizsgálat is $[23,32]$. A TP53-mutációk gyakoriságát figyelembe véve a mutációanalízis nagyobb találati valószínúséggel azonosítja a TP53-defektust, mint a FISH-vizsgálat. Mégis, az utóbbi módszer régóta történő rutinszerű alkalmazására tekintettel, a mutációanalízis annak kiegészítéseként szerepel a TP53-státusz vizsgálatában (5. B ábra). A két eltérés prognosztikai egyenértéküségének köszönhetően az egyik vizsgálat pozitív eredményét követôen gyakorlatilag nem szükséges a másik vizsgálatot is elvégezni, az ugyanis további érdemi információt nem szolgáltat. Mindazonáltal fontos szem előtt tartani az egyes vizsgálatok érzékenységét, ami a FISH esetében megközelítőleg 1\%-ra tehető, míg a Sangerszekvenálással elvégzett mutációanalízis esetében 20\%ra. Ebből kifolyólag, a vizsgálat sikeressége szempontjából kritikus a megfelelő tumorsejtarány megléte a vizsgálati mintában.

A p53-státusznak léteznek egyéb, ritkábban alkalmazott vizsgálómódszerei is. A p53-specifikus immunfestés és a TP53-defektus összefüggése a mindennapi rutin szempontjából felmerülő kérdés lehet. Míg a vad típusú p53 fehérje rövid fél életidejének köszönhetően immunhisztokémiai vizsgálattal nem detektálható, addig a TP53mutáció rendszerint pozitív immunjelölődéshez vezet [34]. Ennek hátterében a hibás funkciójú fehérje megnövekedett fél életideje és akkumulációja áll. Meglepő módon néhány tanulmány beszámolt a 17 p-deletio és a pozitív p53-immunfestés összefüggéséről is [35]. Ez a korreláció minden bizonnyal a másik allélon gyakran megjelenő TP53-mutációknak tulajdonítható, így a p53 immunhisztokémiai vizsgálat nem alkalmas a $17 \mathrm{p}$-deletio megbízható kimutatására. Egy friss, több ezer eset vizsgálatán alapuló tanulmány a TP53-mutációk és p53 fehérjeexpresszió összefüggésével kapcsolatban enyhe diszkrepanciára világít rá. Murnyák és Hortobágyi arról számolnak be, hogy az esetek mintegy 25\%-ában a TP53mutációk nem társulnak immunhisztokémiailag kimutatható p53 fehérjeexpresszióval, ami álnegatív eredményhez vezethet [36]. Napjainkban az immunhisztokémiai analízis háttérbe szorult a vérből elvégezhető, ezáltal minimális beavatkozással járó vizsgálatokkal szemben, ám a viszonylag magas konkordancia miatt különösen a TP53szekvenálási vizsgálattal nem rendelkező laboratóriumokban valós alternatívát jelenthet. Fontos ugyanakkor szem előtt tartani a p53 immunhisztokémiai vizsgálat limitációit, miszerint a mutációk nélkül előforduló 17p-deletiók kimutatására nem alkalmas, a TP53-mutációknak pedig mindössze 75\%-át képes azonosítani. Szerencsére mára hazánkban a TP53-defektust közvetlen módon kimutató FISH és szekvenálás is elérhető vizsgálat.

A TP53-defektus egyéb hematológiai daganatokban szintén elófordul, átlagosan az esetek 10\%-ában, a CLLben leírtakhoz hasonló prognosztikai szereppel. Leggyakrabban akut lymphoid leukaemiában (ALL-ben) fordul elő, ennél a betegcsoportnál is csupán 20\%-ban, ami jóval kevesebb a szolid tumoroknál tapasztalt közel 50\%-nál [37]. Érdekes módon a TP53-defektus két formájának prognosztikai szerepe eltérő az egyes kórképek között: az önálló TP53-mutációk akut myeloid leukaemiában (AML), myelodysplasiás szindrómában (MDS) és CLL-ben, az önálló 17p-deletiók pedig CLL-ben és MDS-ben bírnak szignifikáns negatív hatással a túlélésre. A 17p-deletióval együtt megjelenő TP53-mutációk ALL-ben, AML-ben, CLL-ben és MDS-ben is azonos szignifikáns negatív hatást fejtenek ki a túlélésre [37].

\section{Következtetések}

Az utóbbi években a technológia fejlődésével CLL-ben nemcsak a legrosszabb prognózisú csoport egyre precízebb definiálására nyílt lehetőség, hanem annak kezelésében is nagy áttörések születtek. A kedvezőtlen prognózis hátterében az NGS alkalmazásával egyre több gén (ATM, BIRC3, SF3B1, POT1, KRAS) kerül azonosításra, amelyek klinikai relevanciája ma még kérdéses, ezért rutinszerú vizsgálatuk várat magára $[7,38,39]$. A személyre szabott terápia korszakában ma a legnagyobb kihívás a számos új gyógyszer (például ibrutinib, idelalisib, venetoclax) optimális alkalmazása, lehetóleg előre szelektált betegcsoporton, megfelelő kombinációban és ideig. Ehhez elengedhetetlen a molekuláris diagnosztika integrálása a mindennapi klinikai gyakorlatba, amelyhez az első lépcsőfok a TP53-státusz vizsgálatának kiterjesztése a TP53-mutációk detektálására, amivel további 10\% magas kockázatú beteg azonosítható a teljes betegpopulációban. Az újonnan azonosított gének és a szubklonálisan jelen lévő genetikai laesiók szélesebb körü vizsgálata a következő évtized fő kihívása lesz. Mindez elvezethet majd egy NGS-alapú diagnosztika bevezetéséhez, amelynek segítségével a jövőben a már igazoltan releváns gének vizsgálata gyorsabban és költséghatékonyabban járulhat hozzá az optimális terápiastratégia megválasztásához és ezáltal a betegek hosszabb túléléséhez.

Anyagi támogatás: A közlemény az MTA Lendület program támogatásával készült.

Szerzői munkamegosztás: Valamennyi szerző részt vett a közlemény megírásában, valamint az irodalmi adatok feldolgozásában.

Érdekeltségek: A szerzőknek nincsenek érdekeltségeik.

\section{Irodalom}

[1] Takahashi, T., Nau, M. M., Chiba, I., et al.: p53: a frequent target for genetic abnormalities in lung cancer. Science, 1989, 246(4929), 491-494.

[2] Baker, S. J., Fearon, E. R., Nigro, J. M., et al.: Chromosome 17 deletions and p53 gene mutations in colorectal carcinomas. Science, 1989, 244(4901), 217-221. 
[3] Hollstein, M., Sidransky, D., Vogelstein, B., et al.: p53 mutations in human cancers. Science, 1991, 253(5015), 49-53.

[4] Bouaoun, L., Sonkin, D., Ardin, M., et al.: TP53 Variations in Human Cancers: New Lessons from the IARC TP53 Database and Genomics Data. Hum. Mutat., 2016, 37(9), 865-876.

[5] Wattel, E., Preudhomme, C., Hecquet, B., et al.: p53 mutations are associated with resistance to chemotherapy and short survival in hematologic malignancies. Blood, 1994, 84(9), 3148-3157.

[6] Döhner, H., Stilgenbauer, S., Benner, A., et al.: Genomic aberrations and survival in chronic lymphocytic leukemia. N. Engl. J. Med., 2000, 343(26), 1910-1916.

[7] Nadeu, F., Delgado, J., Royo, C., et al.: Clinical impact of clonal and subclonal TP53, SF3B1, BIRC3, NOTCH1, and ATM mutations in chronic lymphocytic leukemia. Blood, 2016, 127(17), 2122-2230.

[8] Rossi, D., Khiabanian, H., Spina, V., et al.: Clinical impact of small TP53 mutated subclones in chronic lymphocytic leukemia. Blood, 2014, 123(14), 2139-2147.

[9] Puente, X. S., Pinyol, M., Quesada, V., et al.: Whole-genome sequencing identifies recurrent mutations in chronic lymphocytic leukaemia. Nature, 2011, 475(7354), 101-105.

[10] Quesada, V., Conde, L., Villamor, N., et al.: Exome sequencing identifies recurrent mutations of the splicing factor $S F 3 B 1$ gene in chronic lymphocytic leukemia. Nat. Genet., 2012, 44(1), 4752.

[11] Gaidano, G., Ballerini, P., Gong, J. Z., et al.: p53 mutations in human lymphoid malignancies: association with Burkitt lymphoma and chronic lymphocytic leukemia. Proc. Natl. Acad. Sci. U.S.A., 1991, 88(12), 5413-5417.

[12] Rossi, D., Rasi, S., Spina, V., et al.: Integrated mutational and cytogenetic analysis identifies new prognostic subgroups in chronic lymphocytic leukemia. Blood, 2013, 121(8), 14031412.

[13] Zenz, T., Häbe, S., Denzel, T., et al.: Detailed analysis of p53 pathway defects in fludarabine-refractory chronic lymphocytic leukemia (CLL): dissecting the contribution of $17 \mathrm{p}$ deletion, TP53 mutation, p53-p2l dysfunction, and miR34a in a prospective clinical trial. Blood, 2009, 114(13), 2589-2597.

[14] Zenz, T., Eichhorst, B., Busch, R., et al.: TP53 mutation and survival in chronic lymphocytic leukemia. J. Clin. Oncol., 2010, 28(29), 4473-4479.

[15] Chigrinova, E., Rinaldi, A., Kwee, I., et al.: Two main genetic pathways lead to the transformation of chronic lymphocytic leukemia to Richter syndrome. Blood, 2013, 122(15), 2673-2682.

[16] Farooqui, M. Z., Valdez, J., Martyr, S., et al.: Ibrutinib for previously untreated and relapsed or refractory chronic lymphocytic leukaemia with TP53 aberrations: a phase 2, single-arm trial. Lancet Oncol., 2015, 16(2), 169-176.

[17] Deeks, E. D.: Venetoclax: First Global Approval. Drugs, 2016, 76(9), 979-987.

[18] Langerbeins, P., Bablo, J., Rhein, C., et al.: The CLL12 trial protocol: a placebo-controlled double-blind Phase III study of ibrutinib in the treatment of early-stage chronic lymphocytic leukemia patients with risk of early disease progression. Future Oncol., $2015,11(13), 1895-1903$

[19] Stilgenbauer, S., Schnaiter, A., Paschka, P., et al.: Gene mutations and treatment outcome in chronic lymphocytic leukemia: results from the CLL8 trial. Blood, 2014, 123(21), 3247-3254.

[20] Dicker, F., Herholz, H., Schnittger, S., et al.: The detection of TP53 mutations in chronic lymphocytic leukemia independently predicts rapid disease progression and is highly correlated with a complex aberrant karyotype. Leukemia, 2009, 23(1), 117-124.

[21] Zenz, T., Vollmer, D., Trbusek, M., et al.: TP53 mutation profile in chronic lymphocytic leukemia: evidence for a disease specific profile from a comprehensive analysis of 268 mutations. Leukemia, 2010, 24(12), 2072-2079.
[22] Lazarian, G., Tausch, E., Eclache, V., et al.: TP53 mutations are early events in chronic lymphocytic leukemia disease progression and precede evolution to complex karyotypes. Int. J. Cancer, 2016, 139(8), 1759-1763.

[23] Pospisilova, S., Gonzalez, D., Malcikova, J., et al.: ERIC recommendations on TP53 mutation analysis in chronic lymphocytic leukemia. Leukemia, 2012, 26(7), 1458-1461.

[24] Swerdlow, S. H., Campo, E., Pileri, S. A., et al.: The 2016 revision of the World Health Organization classification of lymphoid neoplasms. Blood, 2016, 127(20), 2375-2390.

[25] Rossi, D., Gaidano, G.: The clinical implications of gene mutations in chronic lymphocytic leukaemia. Br. J. Cancer, 2016, 114(8), 849-854.

[26] Malcikova, J., Stano-Kozubik, K., Tichy, B., et al.: Detailed analysis of therapy-driven clonal evolution of TP53 mutations in chronic lymphocytic leukemia. Leukemia, 2015, 29(4), 877885.

[27] Eichhorst, B., Robak, T., Montserrat, E., et al.: Chronic lymphocytic leukaemia: ESMO Clinical Practice Guidelines for diagnosis, treatment and follow-up. Ann. Oncol., 2015, 26(Suppl. 5), v78-v84.

[28] Hallek, M., Cheson, B. D., Catovsky, D., et al.: Guidelines for the diagnosis and treatment of chronic lymphocytic leukemia: a report from the International Workshop on Chronic Lymphocytic Leukemia updating the National Cancer Institute-Working Group 1996 guidelines. Blood, 2008, 111(12), 5446-5456.

[29] Oscier, D., Dearden, C., Eren, E., et al.: Guidelines on the diagnosis, investigation and management of chronic lymphocytic leukaemia. Br. J. Haematol., 2012, 159(5), 541-564.

[30] Zelenetz, A. D., Gordon, L. I., Wierda, W. G., et al.: Chronic lymphocytic leukemia/small lymphocytic lymphoma, version 1.2015. J. Natl. Compr. Canc. Netw., 2015, 13(3), 326-362.

[31] Tam, C. S., Stilgenbauer, S.: How best to manage patients with chronic lymphocytic leuekmia with $17 \mathrm{p}$ deletion and/or TP53 mutation? Leuk. Lymphoma, 2015, 56(3), 587-593.

[32] Hallek, M.: Chronic lymphocytic leukemia: 2015 Update on diagnosis, risk stratification, and treatment. Am. J. Hematol., 2015, 90(5), 446-460.

[33] Eichhorst, B., Cramer, P., Hallek, M.: Initial therapy of chronic lymphocytic leukemia. Semin. Oncol., 2016, 43(2), 241-250.

[34] Lepelley, P., Preudhomme, C., Vanrumbeke, M., et al.: Detection of p53 mutations in hematological malignancies: comparison between immunocytochemistry and DNA analysis. Leukemia, 1994, 8(8), 1342-1349.

[35] Chang, H., Jiang, A. M., Qi, C. X.: Aberrant nuclear p53 expression predicts hemizygous $17 \mathrm{p}$ (TP53) deletion in chronic lymphocytic leukemia. Am. J. Clin. Pathol., 2010, 133(1), 70-74.

[36] Murnyák, B., Hortobágyi, T.: Immunohistochemical correlates of TP53 somatic mutations in cancer. Oncotarget, 2016, 7(40), 64910-64920.

[37] Stengel, A., Kern, W., Haferlach, T., et al.: The impact of TP53 mutations and TP53 deletions on survival varies between AML, ALL, MDS and CLL: an analysis of 3307 cases. Leukemia, 2016 Oct 14. doi: 10.1038/leu.2016.263. [Epub ahead of print]

[38] Herling, C. D., Klaumünzer, M., Rocha, C. K., et al.: Complex karyotypes, KRAS and POTI mutations impact outcome in CLL after chlorambucil-based chemotherapy or chemoimmunotherapy. Blood, 2016, 128(3), 395-404.

[39] Sutton, L. A., Ljungström, V., Mansouri, L., et al.: Targeted nextgeneration sequencing in chronic lymphocytic leukemia: a highthroughput yet tailored approach will facilitate implementation in a clinical setting. Haematologica, 2015, 100(3), 370-376.

(Bödör Csaba dr., Budapest, Üllői út 26., 1085 e-mail: bodor.csabal@med.semmelweis-univ.hu) 